\title{
Word Recognition through Malay Animal Fables
}

\author{
Arbaie Sujud ${ }^{1}$, Normaliza Abd Rahim ${ }^{1} \&$ Nik Rafidah Nik Muhammad Affendi ${ }^{1}$ \\ ${ }^{1}$ Faculty of Modern Languages and Communication, Universiti Putra Malaysia, Malaysia \\ Correspondence: Arbaie Sujud, Faculty of Modern Languages and Communication, Universiti Putra Malaysia, \\ Malaysia. E-mail: arbaie@upm.edu.my
}

\author{
Received: February 6, 2014 Accepted: April 17, 2014 Online Published: May 30, 2014 \\ doi:10.5539/ass.v10n11p252 URL: http://dx.doi.org/10.5539/ass.v10n11p252
}

This work was supported by Geran Putra 9407900- 2013/2015. Universiti Putra Malaysia.

\begin{abstract}
The study focuses on the word recognition using the Malay Animal Fables (MAF) among primary school learners. The objectives of the study were to identify and discuss the words (noun, adjective and verb) from six animal fables. The MAF were taken from the Malay Folklore program. The samples of the study were 100 subjects from two classes of Malay language classrooms. The subjects were picked at random and were interviewed based on the MAF program. The program was based on the stories in the form of songs and the song lyrics. The answers from the subjects were collected and the data were accumulated and anaysed accordingly. The results revealed that the subjects were able to storytell the stories, identify the words and divided the words into noun, adjective and verb. It is hoped that future study will focus on the use of MAF in writing essay.
\end{abstract}

Keywords: word recognition, animal fables, discussion, primary school learners

\section{Introduction}

Animal fable has been the liking of children around the world. It has been used in story telling to ensure the messages in the stories been delivered. Children love stories no matter during the day at school, home or at night before they go to sleep. Reading stories to them will ensure that they will focus on the story and relax their mind and linger around their imagination. This way, children will be more creative and innovative and will try to relate the stories with their lives. Although, some stories were just fairytales, they enjoy every moment of it. In fact, some children will try to imitate the sounds of the animals in order to be part of the story. Thus, animal fable has taught the children the meaning of life and appreciate it (Rahim, 2013a). Moreover, animals that involve in the story will have full description of the their lives. This way, the children will learn more about the animals and the exposure through pictures or video will also make them aware that the animals exist.

There are many things that can be learnt through the animal fables. The moral values, vocabulary, sentence structure, writing, reading, follow-up activities and so on. The activities are carried out with the help of the teacher or parents. On the other hand, reading animal fables can be carried out autonomously. Children will read on their own and they will try to role-play the story by having imaginary friends around them. This way, autonomy learning will help children in being more creative and innovative towards learning (Rahim, 2013a; 2013b). Naginder (2013) agrees with the statement as above and added that autonomous learning is important in learning vocabulary in the classroom. This statement shows that students will learn more effective on their own as compared to having the teachers to guide them all the time. Naginder (2013) adds that learning vocabulary is a difficult task since it is one of the many obtacles faced by language learners since the they are lact in lexical competence which resulted in lagging proficiency levels and inability to relate to the four language skills; reading, writing, listening and speaking. Thus, Naginder (2013) postulates that fostering learner autonomy is becoming one of the most important goals in language teaching in order to fulfill the goal of the education system to produce learners who are able to learn autonomously. Thus, learning vocabulary is one of the activities that helps children or adults in the process of learning a language (Gu \& Johnson, 1996; Blachowicz \& Fisher, 2000; Courtright \& Wesolek, 2001; Gu, 2003a; Gu, 2003b; Sharif, Noor, \& Yunus, 2008; Mokhtar, Rawian, Yahaya, Abdullah \& Mohamed, 2009)

Children are having problems in learning vocabulary or identifying words which can be categorized into noun, adjective, verbs etc. Thus, children will try their best to refer to the dictionary everytime they found any difficult 
words. Thus being conceived as a learners' nightmare and to the extent of language problem, according to Nation (2001), learners regard the lexical competence as one of the major hindrances in learning a language. Segler (2001) agrees and adds that this hindrances is the most common type of lexical errors among language learners. In addition, Zulfa Zakaria (2005) and Azaharee Abdullah \& Abdul Rashid Mohamed (2009) illutrate that learners in Malaysia face learning challenges mainly because the learners are lack in vocabulary and they fail to acquire and comprehend lexical items. Normaliza Abd Rahim \& Siti Nur Aliaa Roslan (2012) postulate that learners have to try their best in overcoming the challenges that they have to face in order to have better learning environment. On the other hand, learners will have to find ways to create a meaningful learning environment with the help of the teachers in the classroom (Abdullah \& Mohamed, 2009).

According to Fauziah Hassan \& Nita Fauzee Selamat (2002), vocabulary exercises rank fourth out of the nine language activities investigated on the frequency of use in the classroom. Students' found that learning vocabulary is not interesting since most of the time, students will have to write their own sentences with the new vocabulary. This way, the students find it less interesting as compared to other activities which need their skill like the listening and speaking activities. Tee Chee Seng (2004) agrees with Fauziah Hassan \& Nita Fauzee Selamat (2002) and adds that students have ranked the vocabulary learning as the lowest ranked. Moreover, students will only have to open the dictionary to find the meaning of the new words and this activity was found not challenging and boring. Likewise, Normaliza Abd Rahim (2013a; 2013b) confirms that students' will have bad perception towards learning the language since the teachers have failed to use interesting teaching and learning processes in the classroom. Thus, Segler $(2001: 1)$ states that vocabulary has often been perceived to be the 'distant cousin' of language teaching and 'the Cinderella of the field of second language acquisition research'. Here, it clearly explains that there is a lack of emphasis on vocabulary as teachers do not play its role in formal classroom environment. Despite the developing of language proficiency, Naginder (2013) adds that vocabulary instruction somewhat tends to take a backseat $\mathrm{n}$ teaching priorities. To add, teacher focuses on the structural signals and grammatical patterns of the language that expected the learners to pick-up the vocabulary on their own, cum with no guidance. Thus, studies by Normaliza Abd Rahim (2013a; 2013b) and Normaliza Abd Rahim \& Siti Nur Aliaa Roslan (2012a) show that the subjects will try their best with the help of technology during the process of learning. Moreover, the teacher also plays a major role in facilitating and guiding them to the right path in learning.

Besides studies on learning vocabulary, there were also studies done on Malay folklore. Thus, the studies were on reading folklore using the big book (Rahim \& Harun, 2010), Malay literature using various means of technology (Rahim \& Harun, 2011; Rahim, 2011a; Isnain \& Rahim, 2012; Rahim, 2013a; 2013b; 2013c), literature and storytelling with special needs children (Rahim, 2011b; Rahim, 2011c; Rahim \& Roslan, 2012a), identifying verbs in stories (Rahim \& Roslan, 2012b), values and proverbs in stories (Rahim, Jang-Gyem \& Ladyanna, 2012). Although, some instruments used were in the English language but most of the stories were taken from the Malay literature genre and Malay folklore. As such, the Malay folklore has given a great impact towards awareness of literature. The studies above showed that the subjects involved were given the opportunity to say their views and opinions on the stories. Apart from that, the subjects involved were also seen happy and content towards the activities given to them. It accordingly showed that the subjects were confident when dealing with the small group discussion along with their peers. It does seem clear that Malay literature and Malay folklore have given the chance for the subjects to appreciate and learn more about them. Besides, with the attention and different classroom environment will make the subjects participate in the activity and they will be able to comprehend the lesson for the day.

Based on the previous studies on vocabulary and Malay literature and folklore, the objectives of the study were to identify and discuss the words from six animal fables from the Malay folklore program.

\section{Methodology}

The subjects of the study consist of 100 samples from two Malay language classrooms. The subjects were nine year old male and female students from a primary school in Malaysia. The subjects were picked at random and they were interviewed based on the Malay folklore program. The Malay folklore program consists of Malay animal fables (MAF) and other types of folklore. Thus this study only concentrates on the MAF. The subjects were to answer the questions given to them based on their views and opinions on the story. Besides storytell the stories from the songs, the subjects were to identify the words and divide the words into noun, adjective and verbs. The data were analyzed and the stories were rewritten according to the songs that were heard by the subjects. According to Stubbs (1983), the term discourse refers mainly to the linguistic analysis of naturally occurring connected speech or written discourse. In this study, the spoken discourse is referred to attempts to study the organisation of language above the sentence or above the clause, such as conversational exchanges. It 
follows that discourse analysis is also concerned with language use in social contexts, and particular with interaction or dialogue between speakers.

\section{Results and Discussion}

The results of the study will be discussed according to each song pertaining to the story from the program. There were six Malay Animal Fables (MAF) from the Malay Animal Fables Program.

In the MAF, the first story entitled Bird of Paradise (Burung Cenderawasih). According to the subjects, the story was about a bird named Bird of Paradise. The bird was so beautiful with its feathers. It will fly and take care of its beautiful feathers only. When the bird lays an egg, it will fly away leaving the eggs unattended. It ignored the egg completely. Thus, another bird came along. The other bird was the sparrow. The sparrow took care of the baby. According to the story as above, all the subjects managed to identify the words for noun, adjective and verb from the lyrics of the song. As for nouns, the subjects listed that the words were; bird (burung), fur (bulu), branch (pohon), egg (telur), nest (sarang), baby (anak), shoot (pucuk) and sparrow (pipit). The nouns were easily found since most of the nouns were in the beginning of the verse. Apart from the nouns, the subjects also listed the adjectives from the story. The adjectives were; beautiful (cantik) and high (tinggi). There were only two adjectives since the story was merely explained and expressed on the verb. Hence, the verbs stated by the subjects were; lay (bertelur), cut (tebang), incubate (mengeram), hatch (menetas), go home (balik), forget (lupa), care (pelihara) and care (berjaga). The verbs mentioned by the subjects were correct and therefore, this showed that the subjects were able to find the difference between the adjectives, nouns and verbs. Moreover, the words listed by the subjects were also mentioned in the story. Thus, the subjects understood the meaning of all the words mentioned. They were able to write new sentences by using the words from the story.

The second MAF entitled Why Black-Haired Crow? (Mengapa Gagak Berbulu Hitam). According to the subjects, the story was about two birds. The crow and the peacock. One day they decided to color their feathers since they only had black feathers. The crow started coloring the peacock with beautiful color. When it was the crow's turn, it saw a corpse and was distracted. It asked the peacock to be quick and pastered the peacock to use only one color. After coloring the crow's feather, it flew away. Due to its greediness, the crow has only black feather. According to the story above, the subjects seemed to be amazed when they understood the story from the lyrics of the song. This was due to the fact that the subjects mentioned they only knew about the black-haired crow. Therefore, the subjects were happy to list all the words from the story. The nouns were; bird (burung), tree (pokok), peacock (merak), haired (bulu), crow (gagak), corpse (bangkai) and river (sungai). The subjects argued and confused with the noun, feather (bulu). They were thinking that the word feather (bulu) was also an adjective. But after arguments and views from other subjects, they decided to put the word under noun. Thus, the subjects mentioned that there a number of adjectives namely, white (putih), beautiful (cantik), happy (gembira), patience (sabar), greedy (gelojoh) and black (hitam). Apparently, there were two words in the Malay language that have the same meaning in the English language (greedy- gelojoh/ haloba). Despite the confusion in the beginning of the lyrics, the subjects also managed to list the verbs namely, colored (warnakan), agree (bersetuju), helping (membantu), eat (makan) and paster (desak). The storyline in the song lyrics was really clear and the subjects understood the whole story. The subjects were seen happy to retell the story by including all the words listed.

The third MFP entitled The Bird Leader (Penghulu Burung). According to the subjects, the story was about a big group of birds that wanted to elect a leader among them. In the beginning, they elected the eagle but later they found out that other small birds were missing. They elected the 'kelengkeng' bird which has the same problem where most of the small birds gone missing. Soon, they decided not to have a leader. Every morning, the wild fowl would wake the other birds by making its sound. According to the story, the subjects listed all the words from the lyrics of the song. There were four nouns mentioned by the subjects namely, forest (hutan), eagle (helang), leader (penghulu), wild fowl (ayam denak) and 'kelengkeng' bird (kelengkeng). Most of the subjects were not able to describe the birds. They knew about the eagle but they did not know how to describe it. Therefore, a few students were seen drawing the eagle and showed it to the other subjects. The subjects also stated the adjective from the lyrics. Only one adjective namely, day (siang) was mentioned in the lyrics. The subjects describe day (siang) as the day they were at school and added that during the day, the sun shines brightly. Thus, the subjects listed all the verbs from the story. The verbs were; meet (bertemu), loss (hilang), promise (janji), devoted (berbakti), follow (mengikut), fulfil (tunaikan) and realize (sedarkan). Although all the words for verbs were difficult to understand but after the subjects managed to understand the whole story, they were able to write new sentences for the verbs. According to the subjects, by writing new sentences for the words, they will understand the meaning.

The fourth MFP entitled The Smart (Si Pintar). According to the subjects, the story from the lyrics were about 
two roosters. Jalak was conceited while Biring was nice, clever and dilligent. One day, the Biring came to see Jalak and said that there was another rooster who was stronger than Jalak. Jalak was angry and agreed to meet the rooster. It did not realize that Biring has put a mirror in order to ensure that Jalak will be meeting itself. Jalak fought with the mirror and ended very tired and defeated. Jalak was embarrased when Biring mentioned about the mirror. According to the story above, the subjects managed to list all the words from the lyrics of the song. The subjects listed the noun namely, village (kampung), rooster (ayam jantan), small house (rumah kecil) and mirror (cermin). The nouns were related to their village since most of the subjects have roosters and they live in the village. Therefore, the subjects were able to relate the story with their lives. As for adjective, the subjects have a long list the words. The adjectives words namely, conceited (bongkak), nice (baik), rajin, smart (pintar), proud (bangga), angry (berang), strong (kuat), quick (tangkas), fierce (garang), shy (malu) and stupid (bodoh). The subjects were discussing about the rooster and they were happy to describe about it. The subjects seemed to like the story since they imagined about the rooster at home. The subjects agreed to the description of the rooster and were seen smiling when the roosters acted silly. Thus, the subjects listed the verbs from the story. The verbs namely, meet (bertemu), compete (bertarung), face-to-face (bersemuka), agree (bersetuju), meet (berjumpa), jump (melompat), go up (naik), shock (terkejut), predict (diduga), fight (melawan), put (letak), swoop (terkam), backward (undur), angry (marah), play (mempermainkan) and tired (letih). There were sixteen verbs allocated in the story. The subjects seemed to be excited listing all the verbs since they remembered the story well and they were able to relate with their knowledge about the rooster. Moreover, the subjects seemed to be able to understand the meaning of all the verbs listed. In fact, the subjects were able to give examples of other sentences to describe the verbs.

The fifth MFP entitled The Flamingo and the Deer (Bangau dan Kancil). According to the subjects, the story comprises of two main characters. The flamingo and the deer. One day, the deer was trying to show to the flamingo that it is the cleverest animal. Both animal have found a big rice crusts. They decided to eat the rice but the crusts was used as a boat to go across the river. The deer was trying to make fun of the flamingo and ate the middle of the crusts while the flamingo was paddling. The flamingo warned the deer that the crusts might sink but was ignored by the deer. Soon, the crusts went down the river and the flamingo flew away. The deer was shocked and swam to the river bank. The deer regreted its behaviour that made him the silly animal. According to the story as above, the subjects stated that there were seven nouns found in the lyrics of the song. The nouns namely; flamingo (bangau), deer (kancil), rice crusts (kerak nasi), rice (nasi), boat (perahu), shoulder (bahu) and water (air). It seemed that the subjects were able to differentiate between rice crusts (kerak nasi) and rice (nasi). The subjects mentioned that both are the same accept that they have not eaten the rice crusts (kerak nasi) before. In addition, the subjects said that the rice crusts (kerak nasi) were bitter and dark in color and usually it can not be eaten. Other than that, the subjects also mentioned the adjectives from the lyrics of the song. The adjective namely; good (baik), brilliant (bijak), clever (pandai), intelligent (cerdik), tall (tinggi), middle (tengah), and up (naik). There were seven adjectives and all the adjectives were about the flamingo and the deer. Hence, the subjects managed to differentiate between brilliant, clever and intelligent. In the beginning, the subjects were seen discussing about the three words which have nearly the same meaning but after they relate the story with the words, they found that the words differed. Thus, the subjects mentioned eleven verbs from the lyrics of the song. The subjects were able to say the verbs with the characters. This way, the other subjects were able to understand which animal had done the activity. The verbs namely; eat (makan), show off (berlagak), lie (ditipu), paddle (berkayuh), fight (berlaga), lie (menipu), see (melihat), fly (terbang), saving (menyelamatkan), bothered (dipeduli) and feel (terasa). It was obvious that the subjects were actively participated in the discussion of the verbs since they were seen showing the gestures of the verbs to their friends.

The sixth MFP entitled, The Fox Cave (Gua Musang). According to the subjects, the story comprises of one main character. The character was a group of fox. According to the story, the foxes live in a cave. During the day, they will sleep inside the cave and at night they will hunt for food. One day, a hunter reached the cave. He saw the foxes and all of them ran away. From that day onwards, the hunter had named the cave the Fox Cave. According to the story as above, the subjects stated that they were seven nouns in the lyrics of the song. The list of nouns namely; cave (gua), fox (musang), rooster (ayam hutan), bird (burung), stone (batu), hunter (pemburu) and fox cave (gua musang). The subjects stated that the nouns were found by looking at the characters and the things around it. It can be seen that the subjects were giving their views on the nouns. Besides that, the subjects were able to list out the adjectives from the lyrics of the song. The adjectives namely; black (hitam), red (merah), brown (perang), smelly (busuk), fragrant (wangi), day (siang) and night (malam). The adjectives were merely describing the fox and the surrounding. The subjects seemed to be imagining the story and described the story to their friends. Other than that, the subjects listed the verbs from the lyrics of the song. The verbs stated namely; lived (diami), fight (berkelahi), find (mencari), catch (menangkap), lost (sesat), sleep (tidur), tired (letih), full 
(kenyang), shocked (terperanjat), run (lari), scattered (bertempiaran) and see (melihat). The subjects managed to find twelve verbs from the lyrics of the song. It can be seen that the verbs were correct and the subjects did not miss any of it. The subjects were also seen showing gestures in order to explain about the verbs to their friends.

In accordance to the results discussed above, it can be concluded that all the subjects found teaching and learning through word recognition of animal fables were interesting and fun. The subjects stated that the activity was different from other activities that they had in the classroom. They added that the discussion about the song lyrics was fun and challenging since they have to remember the whole story. Moreover, the subjects confirmed that the understanding of the story was important in order to allocate the right words for noun, adjective and verb. Subsequently, without the knowledge of the story, the subjects will not be able to differentiate between the noun and adjective or noun and verb. This way, the subjects were to be careful with the discussion and when listed down all the words. Despite being careful with the list, the subjects were seen happy and content with the activity. They were seen concentrating with the storylines that were said by their friends. Apparently, the subjects participated in the group discussion in order to understand the story or share their views and comments towards the stories based on the lyrics of the songs. This study is parallel to the study done by Normaliza Abd Rahim (2013a;2013b) where it involved the use of technology in learning. Thus, this study is similar to the study done by Naginder (2013) where learning vocabulary has shown great interest among students.

\section{Conclusion}

This study implicates students, teachers and lecturers in creating a fun environment in teaching and learning. Thus, both parties as in students and teachers/lecturers will have to look at the importance of word recognition when dealing with stories that were written long time ago. As said in the beginning of the study, the stories were taken from the Malay folklore which started long time ago and was carried down from generation to generation. In order to preserve the story and being appreciated by the younger generation, the Malay folklore was created in a fun and creative way. Hence, the collaboration between the teachers/lecturers with the researcher will therefore help in many ways to create a new classroom environment. Other than that, the study implicates the author or writer of storybook in creating stories that are fun and enjoyable. Hence, to inculcate the love towards reading among children at school. It is hoped that future study will focus on the use of MAF in writing essay.

\section{References}

Blachowicz, C. L. Z., \& Fisher, P. (2000). Vocabulary instruction. In M. L. Kamil, P. B. Mosenthal, P. D. Pearson, \& R. Barr (Eds.), Handbook of Reading Research (Vol. 3, pp. 503-523). Mahwah, NJ: Lawrence Erlbaum.

Courtright, M., \& Wesolek, C. (2001). Incorporating interactive vocabulary activities into reading classes. English Teaching Forum, 39(1), 2-9.

Gu, P. Y. (2003a). Vocabulary learning in a second language: person, task, context and strategies. TESL-EJ, 7(2). Retrieved from http://tesl-ej.org/ej26/a4html

Gu, P. Y. (2003b). Fine brush and freehand: The vocabulary-learning art of two successful Chinese EFL learners. TESOL Quarterly, 37(1), 73-104. http://dx.doi.org/10.2307/3588466

Gu, P. Y., \& Johnson, R. K. (1996). Vocabulary learning strategies and language learningoutcomes. Language Learning, 46(4), 643-679. http://dx.doi.org/10.1111/j.1467-1770.1996.tb01355.x

Hassan, F., \& Selamat, N. F. (2002). Why aren't students proficient in ESL: The teachers' perspective. The English Teacher, 31, 107-123.

Isnain, S. M., \& Rahim, N. A. (2012, June). Gaya Ujaran Berbantu Komputer dalam Kalangan Kanak-Kanak Sekolah Rendah. Jurnal Bahasa, 12(1), 126-150.

Kaur, N. (2013, September, 7-16). The Need for Autonomous Vocabulary Learners in the ESL Classroom. Gemaonline Journal of Language Studies, 13(3).

Mokhtar, A. A., Rawian, R. M., Yahaya, M. F., Abdullah, A., \& Mohamed, A. R. (2009). Vocabulary learning strategies of adult ESL learners. The English Teacher, 38, 133-145.

Nation, I. S. P. (2001). Learning vocabulary in another language. Cambridge: Cambridge University Press. http://dx.doi.org/10.1017/CBO9781139524759

Rahim, N. A., \& Harun, N. I. (2010). Students Perception towards the Usage of the Big Book. Gading Business and Management Journal, 14, 47-54.

Rahim, N. A., \& Harun, N. I. (2011). Emotions among the Primary School Students: A Malay Drama Program 
(Software). UPENA Johor, 10, 185-198.

Rahim, N. A., \& Roslan, S. N. A. (2012a). Kata Kerja Melalui Penerapan Kinestetik Pelajar Sekolah Rendah di Nottingham United Kingdom: Satu Analisis. Jurnal Bahasa Brunei, JB, 26, 96-104

Rahim, N. A., \& Roslan, S. N. A. (2012b). Analisis Penceritaan Semula Pelajar Asperger Melalui Grafik Digital. Jurnal Bahasa, 27, 186-192.

Rahim, N. A. (2011a, June). Music Video Clip Storyboard Writing among Focus Group Learners of Media. Global Media Journal Malaysia, 1(1), 78-91.

Rahim, N. A. (2011b). Gangguan Dalam Sesi Bercerita Kanak-Kanak Asperger. Jurnal Linguistik, 13, 1-10.

Rahim, N. A. (2011c). Penerapan Nilai Sosial Melalui Lakonan Cerita dalam Kalangan Pelajar Sindrom Asperger. Jurnal Sains Sosial dan Pengurusan Teknologi UMP, 3, 25-34.

Rahim, N. A. (2013a, April). Literature Computer Program among Primary School Learners. TOJET: The Turkish Online Journal of Educational Technology, 12(2), 193-199.

Rahim, N. A. (2013b). Identification of Verbs in a Short Film Pasport Ekspres. The Public Administration and Social Policies Review, 10, 37-45.

Rahim, N. A. (2013c, July). Adjectives Identification in Television Advertisements. TOJET: The Turkish Online Journal of Educational Technology, 12(3), 15-20.

Rahim, N. A., Jang-Gyem, K., \& Ladyanna, S. (2012). Peribahasa Melalui Aspek Nilai Murni Pelajar Korea (in Malay Language). Pendeta Jurnal Bahasa dan Sastera Melayu, 3, 181-194.

Segler, T. A. (2001). PhD Research proposal: Second language vocabulary acquisition and learning strategies in ICALL environments. Retrieved January 9, from http://homepages.inf.ed.ac.uk/s9808690/finalpaper2.pdf

Seng, T. C. (2004). How alienated are our students in the ESL class? In J. Mukundan, D. Z. Abidin, \& A. A. Hussin (Eds.), ELT Matters 1:Issues in English language learning and teaching (pp. 255-260). Serdang: Universiti Putra Malaysia Press.

Sharif, T. I. S. T., Noor, M. Y. M., \& Yunus, H. (2008). Vocabulary knowledge: Students' profiling. Voice of Academia (Special Edition), 3, 27-39.

Zakaria, Z. (2005). Dictionary as tool in vocabulary acquisition for rural students. Unpublished master's dissertation, Universiti Sains Malaysia, Pulau Pinang, Malaysia.

\section{Copyrights}

Copyright for this article is retained by the author(s), with first publication rights granted to the journal.

This is an open-access article distributed under the terms and conditions of the Creative Commons Attribution license (http://creativecommons.org/licenses/by/3.0/). 